\title{
Examining Work Engagement and Job Satisfaction Variables in their Relations with Job Performance and Intention to Quit
}

\author{
Bilal ÇANKIR iD a Selma ARIKAN iD b \\ a İstanbul Medeniyet Üniversitesi, İstanbul, Türkiye. bilal.cankir@medeniyet.edu.tr \\ b İstanbul Medeniyet Üniversitesi, İstanbul, Türkiye. selma.arikan@medeniyet.edu.tr
}

\begin{tabular}{|c|c|}
\hline ARTICLE INFO & ABSTRACT \\
\hline $\begin{array}{l}\text { Keywords: } \\
\text { Work Engagement } \\
\text { Job Satisfaction } \\
\text { Performance } \\
\text { Intention to quit } \\
\text { Education Sector }\end{array}$ & $\begin{array}{l}\text { Purpose - In this study, work engagement and job satisfaction variables; two positive constructs } \\
\text { related with employees attitudes to work; and their associations with employee related outcomes } \\
\text { such as performance and intention to quit were analysed via the data collected from } 988 \\
\text { participants employed in education sector. We aimed to understand the associations and } \\
\text { interactions of work engagement and job satisfaction on the outcome variables intention to quit } \\
\text { and employee performance. }\end{array}$ \\
\hline $\begin{array}{l}\text { Received } 2 \text { April } 2019 \\
\text { Revised } 14 \text { June } 2019 \\
\text { Accepted 21 June } 2019\end{array}$ & $\begin{array}{l}\text { Design / Methodology/ Approach - The data of the study were collected by using UWES (Very } \\
\text { Short Form) Utrecht Work Engagement Scale, Job Satisfaction Scale (Babin and Boles, 1998), } \\
\text { Intention to Quit Scale (Babin and Boles, 1998) and Performance Scale (Kirkman and Rosen, 1999). } \\
\text { Data were analysed by using Simple and Multiple Linear Regression analyses and Sobel tests. }\end{array}$ \\
\hline \multirow[t]{2}{*}{$\begin{array}{l}\text { Article Classification: } \\
\text { Research Article }\end{array}$} & $\begin{array}{l}\text { Findings - The results of the analyses confirmed that work engagement and job satisfaction were } \\
\text { two interrelated but different constructs. It revealed that, job satisfaction was a stronger predictor } \\
\text { of intention to quit compared to work engagement, and it was a mediator between work } \\
\text { engagement and intention to quit. Work engagement was found to be a stronger predictor on } \\
\text { employee performance compared to job satisfaction, and it acted as a mediator between job } \\
\text { satisfaction and job performance. }\end{array}$ \\
\hline & $\begin{array}{l}\text { Discussion - The results denoted that job satisfaction seems to be a more powerful predictor on } \\
\text { negative attitudes such as intention to quit whilst work engagement may be more related to } \\
\text { positive results like performance. The findings of the study were evaluated by considering the } \\
\text { previous literature on job satisfaction and performance relationship, which have been debated } \\
\text { since 1950s. In accordance with the current literature on work engagement, it was concluded that } \\
\text { work engagement could be a better predictor of performance for the education sector employees. }\end{array}$ \\
\hline
\end{tabular}

\section{Introduction}

While organizations are dealing with the increasing competitive environment and the new paradigm of trade wars added there upon, they desire to acquire maximum benefit from their most valuable asset, human resources; that is to say, they desire to hire high-performing employees. Accordingly, educational institutions are attempting to create a dynamic working environment, where employees can perform high performance for the business and organization and to make employees loyal to the work and the institution. In this context, employee performance is always a research topic for the researchers working in the field of organizational psychology and organizational behavior. For this reason, many studies have been conducted to investigate the relation between different employee attitudes and performance (Ritchie and Newby, 1989; Milani, 1975; Damavandi and Kashani, 2010).

Job satisfaction is one of the most studied variables regarding its relation with employee performance. On the other hand, performance is related to the satisfaction and well-being of the employee; however, employees' engagement to work is seen as a factor that can also positively affect the performance. Work engagement, which consists of vigor, dedication and absorption sub-dimensions, is defined as a positive and satisfying mental state of work (Schaufeli and Bakker, 2003), has attracted a great interest among academicians, although it has been included in the academic literature only for 15 years (eg, Schaufeli and Bakker 2004; Xanthopoulou, Bakker, Demerouti and Schaufeli, 2009; Kompaso and Sridevi, 2010;

\section{Suggested Citation:}

Çankır, B., Arıkan, S. (2019). Examining Work Engagement and Job Satisfaction Variables in their Relations with Job Performance and Intention to Quit, İşletme Araştırmaları Dergisi, 11 (2), 1133-1150. 


\section{B. Çankır - S. Arıkan 11/2 (2019) 1133-1150}

Garczynski, Waldrop, Rupprecht and Grawitch, 2013; Alfes, Shantz, Truss and Soane, 2013; Yoon and Kim, 2014; Van Berkel, Boot, Proper, Bongers and van der Beek, 2014; Seppälä et al., 2015; Bakker and Albrecht, 2018). In addition, the number of researches and articles published in this subject is increasing and there have been various studies on scale development (eg, Ardıç and Polatçı, 2009; Özsoy, Filiz and Semiz, 2013; Kanten and Yeşiltaş, 2013; Turgut, 2013; Çankır and Yener, 2017; Arslan and Demir, 2017, Taş, 2018). In this study, "Work Engagement" concept, which was introduced to the literature by Schaufeli et al., and translated into Turkish by Turgut (2010) as "çalışmaya tukunluk", will be examined with its effects on employees working in education sector.

On the other hand; job satisfaction is one of the oldest concepts in the field of organizational psychology and behavior with its positive relation to work performance. Job Satisfaction's relation with performance and other business outcomes are investigated much more, compared to the work engagement construct. However, even though positive relationships between job satisfaction and job performance can be seen in the studies and meta analyses, it has been observed that the correlation coefficients are generally low and lowmedium level (e.g. Brayfield and Crockett, 1955; Vroom, 1964; Petty, McGee and Cavander, 1984; Lafaldano. and Muchinsky, 1985; Judge, Thoresen, Bono and Potton, 2001, Wright 2006, Demerouti and Cropanzano, 2010). Therefore, researchers such as Lyubominsky, King and Diener (2005), Wright (2006) and Zelenski, Murhy, and Jevkins (2008) have argued that concepts related to positive emotions such as employee's wellbeing and happiness may better predict performance other than job satisfaction (cited in, Demerouti and Cropanzano, 2010).Unlike negative emotions, employees with positive emotions have various personal resources such as physical (physical skills, such as being healthy), social (such as having good relationships, having social support networks), intellectual (like knowledge) and psychological (self-efficacy, optimism) resources. These personal resources are very important in dealing with job demands and performing well (Bakker, Tim \& Derks, 2012).On the other hand negative employee attitudes like intention to quit emerges based on reasons such as; the inability to have these resources or these resources to be under the personal expectations, the high number of job demands and the lack of management support, blocked future career paths and progress. Job satisfaction is a positive attitude towards employees' work and this attitude is influenced by organizational resources. (Luthans, 1995, cited by Yumuşak, Özafşarlıŏglu and Yıldız, 2013).Based on these points; this research will examine the associations of work engagement and job satisfaction as antecedent variables to outcome variables intention to quit and performance.

\subsection{Work Engagement}

The word engagement is derived from the verbal root "to engage" in English. In the original sense, the word "to engage" is defined as holding a thing or someone hostage, or promising something (McIntosh and Turnbull, 2005). Research on work engagement has been made in different perspectives. The first of these, Personnel Engagement concept, was first used by Gallup Consulting (Saks, 2006). According to Gallup's definition, personal engagement is defined as someone's emotional bonding with their work and co-workers, and a state of cognitive willingness and enthusiasm (Schaufeli and Bakker, 2010).It was Kahn who first identified the concept of Personal Engagement in the academic and psychological context ( as cited in, Shuck and Wollard, 2010). William A. Kahn (1990) stated that the harmony between employees' personalities and job roles has varying levels of physical, cognitive and emotional impacts on the members of the organization and this has different outcomes for both their work and their experiences. Kahn revealed the concept of personal engagement and attempted to explain the psychological situation that effected it with meaningfulness, trust and convenience dimensions (Kahn, 2012).As it can be seen from the definition, it is seen that personal engagement has a focus on the personal characteristics of the employee and the motivation of the person to do the work. Job engagement, another concept examined in the literature related to personal engagement, was defined by Maslach and Leiter as the opposite of the concept of burnout. Work engagement is defined as the employee not showing symptoms of burnout (Maslach and Leiter, 1997). These researchers have described work engagement, considering the definition of burnout. Maslach and Leiter's work on burnout has provided identification with such a perspective. While Maslach and Leiter define three dimensions of burnout as emotional exhaustion, desensitization and low sense of achievement, they refer to three dimensions of engagement as energy, commitment and competence. Researchers, as noted, particularly focused on the claim of burnout to be the opposite of work engagement. 
The construct of work engagement, which is the most recent approach to personal engagement, has been introduced to the literature by Wilmar B. Schaufeli et al. These researchers describe the work as a positive and satisfying mental state of work, composed of the sub-dimensions of engagement, vigor, dedication and absorption (Schaufeli and Bakker, 2003). Work engagement, with its emotional-cognitive dimensions, is a continuous state, not a temporary one for a short period of time (Koyuncu, Burke and Fiksenbaum, 2006). From the three sub-dimensions of work engagement emphasized in the definition, vigor is expressed as "a high level of energy and mental resilience while working". In other words, it means that one is willing to give his/her energy to work, and persistent even if they face challenges. The dedication is related with the emotions of "significance, enthusiasm, inspiration, pride and challenge" (Schaufeli, Salanova, GonzalezRoma and Bakker, 2002). Absoption, is defined as "being fully focusing and deeply involved in one's work whereby time passes quickly and one has difficulties with detaching oneself from work" (Schaufeli et al., 2002).

Work engagement and being a workaholic can be considered as two interrelated concepts, which are mostly mixed up with each other. According to Oates, who was the first person discussing the concept of workaholism in the literature, workaholism is defined as the mood that the employees feel uncomfortable when they leave the work, and become coalesced into the work up to the degree of dependence (Oates, 1971). Workers who are engaged to work, on the contrary to the negative features seen in workaholism, are not extremely and impulsively dependent on their jobs, but their work is a source of entertainment for them (Bakker and Demerouti, 2008). Accordingly, work engagement is thought to be a different construct from workaholism (Schaufeli et al., 2006).

Studies have shown that work engagement is a significant predictor on high work performance (Bakker, Schaufeli, Leiter and Taris, 2008). For example, Reijseger, Peeters, Taris, and Schaufeli (2017) have shown that food industry employees who are highly engaged to work have higher scores in terms of both extra and in-role performance. In addition, a negative association was found between the counterproductive or deviant work behaviours and work engagement. Fredrickson (2003) also stated that positive emotions caused by work engagement lead to a better use of cognitive resources by expanding the employee's point of view and thus enhancing employee's performance. Many studies in different cultures and sectors have always emphasized the positive relationship between work engagement and job performance (eg Bakker and Bal, 2010; Bakker, Demerouti, Verbeke, 2004; Christian, Garza and Slaughter, 2011; Giervel and Bakker, 2005; Salanova, Agut and Peiro, 2005; Schaufeli, 2009; Schaufeli, Taris, and Bakker, 2006)

\subsection{Job satisfaction}

Job satisfaction is the positive attitude that comes out when an employee evaluates or experiences his or her work (Locke, 1969). Job satisfaction is an emotional assessment based on many factors in terms of work and therefore it cannot be touched nor seen, it only emerges with expressions and behaviors. Generally, job satisfaction is associated with employees' evaluations about how much the results and the outputs meet their work related expectations (Çankır, 2016).Job satisfaction is the evaluation of work conditions (work itself, behaviors and attitudes of management and managers, organizational climate) or results obtained from work (wage, job security) by the employee. Job satisfaction consists of internal analysis, evaluation and response to the perceptions of the employee about the work and organizational climate through the system of expectations, rules and values (Schneider and Snyder, 1975, cited by Çekmecelioglu, 2005). The most important feature of job satisfaction is that it is emotional rather than being mental. Job satisfaction is the subjective evaluation of the employees on their job. However, in making this evaluation, it is affected by many of the above mentioned variables. Job satisfaction was examined by many researchers in the literature; the studies conducted in Turkish literature examined the relationship between job satisfaction and concepts such as management style and working conditions (Erdil et al., 2011), life satisfaction (Asan and Erenler, 2008), organizational trust (Yazicioglu, 2009) and work commitment (Kömürcüoğlu, 2003).

Job satisfaction is a positive concept just as work engagement. In addition, both concepts can be observed with the behaviours of employees because they characterize their employee attitudes. However, work engagement is related to dedication and commitment, unlike matters of job satisfaction; It is also defined as the work of employees with his/her own will and hence their performance are likely to go beyond the given job descriptions to enable the organization for achieving its goals (Bakalc1, 2010).In the literature, there are 
B. Çankır - S. Arıkan 11/2 (2019) 1133-1150

studies investigating the relationship between both variables (Giallonardo et al., 2010; Høigaard et al., 2012; Yeh, 2013; Rayton and Yalabik, 2014). In the results of the aforementioned research, there is a significant and positive relation between job satisfaction and work engagement. In Turkey, the relationship between job satisfaction and work engagement is investigated by Şahin and Çakır (2010) and it was concluded that there was a significant and positive relationship between the two variables. In this context, we also expect a positive and significant association between work engagement and job satisfaction of the employees in the education sector.

Hypothesis 1: There is a positive relation between work engagement of the employees and job satisfaction.

\subsection{Intention to Quit}

No employee wants to start a job with an intention of leaving. With some negative developments, people who are especially experiencing gaps in psychological contracts (Argyris, 1960; Rousseau, 1989) and people whose expectations have not been met (Rousseau, 1995; cited by Çankır, 2010) may begin to think of breaking away from the organization over time. Intention to quit can be defined as making an informed decision or intending to leave the organization or the organization climate (Tett and Meyer, 1993).In another definition, intention to quit means the disengagement of the employee from the organization and the organization's environment and employee only fulfils his/her job roles at the minimum required level (Seçer, 2009).

Positive emotion theory is a theory associated with the intention to quit. According to Fredrickson (2001), the personal resources of the employees who receive positive feedback or appreciation are prone to develop further positive emotions, and these positive emotions induce the individuals to push themselves to try new things. At the same time, due to the norm of reciprocity theory, the employee receiving positive feedback will do his/her best in response (Gouldner, 1960; as cited in Çankır, 2016). Conversely, if the organization does not appreciate an employee sufficiently and does not provide positive feedback and resources to the employee, it cannot be expected for the employees to have positive thoughts about the place where they are working. If, after a certain time, the organization cannot respond to the expectations of its employees and is indifferent to their development, the employees may consider leaving the job and the organization. Although this theory is a general theory, there may be variations according to the organizational conditions and individual characteristics.

Bhatnagar (2012) concluded that there was a significant and negative relationship between work engagement and intention to quit. In another study, Hallberg and Schaufeli (2006) achieved to find similar results and found a significant and negative association between work engagement and intention to quit. As a result of the research conducted by Yalabik et al. (2013), a significant and negative relationship was also found between two variables. Researches where both variables had been investigated were also conducted in Turkey. In one of these studies (Akgün, 2017), in line with previous studies, emphasis is placed on the negative relationship between the work engagement and intention to quit. Again in the Turkish sample, Harputluoğlu and Polat (2017) showed that the relationship between work engagement and intention to quit was significant and negative. In this context, we also expect a negative and significant relationship between work engagement and intention to quit.

Hypothesis 2: There is a negative relationship between work engagement of the employees and intention to quit.

Many previous studies have identified a significant and negative relation between job satisfaction and intention to quit (Begley and Czajka, 1993; Lum et al., 1998; Cote and Morgan, 2002; Scott et al., 2003; Limve et al. , 2017). There are also several studies that has investigated the relation between job satisfaction and intention to quit; for example, Çekmecelioğlu (2006) concluded that there is a negative relationship between two variables. In another study, Poyraz and Kama (2008) also found a negative relationship between job satisfaction and intention to quit. In this context, we also expect a negative association between job satisfaction and employees' intentions to quit.

Hypothesis 3: There is a negative relationship between job satisfaction of the employees and intention to quit. 
B. Çankır - S. Arıkan 11/2 (2019) 1133-1150

A literature review was conducted in order to find the studies that examined the variables of work engagement, job satisfaction and intention to quit together, and only one study was found (Høigaard et al., 2012). According to the results of this study, It was concluded that there is a significant and positive relationship between work satisfaction and work engagement and both work engagement and job satisfaction were negatively associated with intention to quit. No similar study could be found examining all three variables, and conducted in Turkey.

\subsection{Job Performance}

According to TDK (2018), performance means "success, achievement while performing any work, or in a game, job, etc.". Job performance has a process dimension (behavioral) and an outcome dimension (Borman and Motowidlo, 1993). The behavioural dimension emphasizes what the employees do in the workplace, i.e. the action itself (Campbell et al., 1990). Performance includes specific behaviours (e.g., sales conversations with customers, programming computer software, assembling parts of a product). The outcome dimension of the job performance focuses on the outcome of the person's behaviour. However, the outcome dimension of the performance may be affected by other external factors. For example, although a salesperson does his or her job well, the sales figure may be low for some reason depending on customers. Or, although a teacher in high school instructs the courses very well, the success of the course may be low due to low motivation and unwillingness of the students to learn the course materials. Therefore, job performance should be addressed in a multifaceted way.

As mentioned earlier, the positive relation between work engagement and job performance has been emphasized by researchers many times. Meta- analysis studies showing that the work engagement is an important indicator of job and organizational performance is also available in the literature (Bakker, 2017). There are studies in the literature that detects the relationship between work engagement and job performance as significant and positive (eg Salanova, Agut and Peiró, 2005; Shimazu and Schaufeli, 2009; Rich, Lepine and Crawford, 2010; Demerouti, Bakker and Gevers, 2015; , 2016; Reijseger, Peeters, Taris and Schaufeli, 2017).

The relation between job satisfaction and performance has been examined by many researchers in the literature in both Turkey and the rest of the world (Ceylan and Ulutürk, 2006; Yazicioglu, 2010; Gurbuz and Yüksel, 2011) and significant and positive relations were determined between both variables in related researches. In addition, also in studies that investigate job satisfaction, job performance and intention to quit together (Poon, 2004; Erkuş and Findıkl1, 2013), it was concluded that there is a significant and positive relationship between job satisfaction and work engagement and there are significant and negative associations of work engagement and job satisfaction variables to intention to quit.

When the literature was reviewed, the studies examining the relation between intention to quit and the performance share the finding of significant and negative correlation between two variables (Tuten and Neidermeyer, 2004; Zimmerman and Darnold, 2009; Çelik and Çıra, 2013; Begenirbaş and Çalışkan, 2014 ; Fabi et al., 2015). There was only one study examining the relation between work engagement and intention to quit, and performance (Halbesleben and Wheeler, 2008); this study found out that the intention to quit had a significant and negative relation with the other two variables whereas there was a significant and positive relationship between work engagement and job satisfaction.

Based on these literature we expect that:

Hypothesis 4: There is a positive relationship between work engagement of employees and performance.

Hypothesis 5: There is a positive relation between employees' job satisfaction and performance.

Hypothesis 6: There is a negative relation between employees' intention to quit and performance.

In this context, our study is important since it examines the associations among work engagement, job satisfaction, intention to quit and performance at the same time, and it focuses on the education sector employees who have a critical importance for our country. 


\section{Method}

2.1. Sample The sample of the study consisted of 988 participants in the education sector (working in kindergarten, primary school, and secondary education and higher education institutions). 393 of the participants were male and 595 were female; 63 were also senior executives, 178 were mid-level/ junior managers and 747 were experts. Other demographic data such as age, seniority, marital status and education level of the participants were categorically collected and these characteristics are summarized in Table 1. As seen in the table, the majority of the participants are young participants between the ages of 18-39. Most of the participants have a bachelor's degree in higher education.

Table 1: Demographic Characteristics of Participants

\begin{tabular}{|c|c|c|c|c|c|c|c|}
\hline & Male & Female & & & & & \\
\hline \multirow[t]{2}{*}{ Gender: } & 393 & 595 & & & & & \\
\hline & $18-24$ & $25-32$ & $33-39$ & $40-49$ & $50-59$ & $60-64$ & Over 65 \\
\hline \multirow[t]{2}{*}{ Age Range } & 366 & 269 & 189 & 125 & 33 & 5 & 1 \\
\hline & Married & Single & Other & & & & \\
\hline \multirow[t]{2}{*}{ Marital Status } & 388 & 577 & 23 & & & & \\
\hline & \multicolumn{2}{|c|}{ Senior Executive } & $\begin{array}{r}\text { Intern } \\
\text { Subordina }\end{array}$ & $\begin{array}{l}\text { diate / } \\
\text { Executive }\end{array}$ & \multicolumn{2}{|c|}{ Expert } & \\
\hline \multirow[t]{2}{*}{ Position } & \multicolumn{2}{|c|}{63} & \multicolumn{2}{|c|}{178} & \multicolumn{2}{|c|}{747} & \\
\hline & $\begin{array}{l}5 \text { months } \\
\text { and less }\end{array}$ & $\begin{array}{c}6 \text { months - } 1 \\
\text { year }\end{array}$ & $1-2$ years & 3-4 years & 5-7 years & $8-10$ years & $\begin{array}{l}10 \text { years } \\
\text { and above }\end{array}$ \\
\hline \multirow[t]{2}{*}{ Seniority } & 154 & 111 & 168 & 192 & 122 & 61 & 180 \\
\hline & $\begin{array}{c}\text { Primary } \\
\text { school }\end{array}$ & High school & $\begin{array}{l}\text { Undergrad } \\
\text { uate }\end{array}$ & Graduate & Doctorate & & \\
\hline $\begin{array}{l}\text { Education } \\
\text { level }\end{array}$ & 12 & 96 & 753 & 102 & 25 & & \\
\hline
\end{tabular}

\subsection{Measurement:}

The survey used for data collection consisted of five sections. First of all, a demographic information form was used to determine the age, gender, position, seniority, marital status and education level of the participants. In addition to these questions, data related to the variables of the study were collected by using the Utrecht Work Engagement Scale Very Short (UWES Very Short), Job Satisfaction Scale, Performance Scale and Intention to Quit Scale.

2.2.1. Utrecht Work Engagement Scale Very Short Form (UWES Very Short): This scale is a very short form, consisting only 3 items, of the Utrecht Work Engagement Scale (UWES) form, which is developed by Schaufeli et al. and originally consisting of 17 items and has a short form consisting of 9 items. It was shown in the study by Schaufeli, Shimazu, Hakanen, Salanova and De Witte (2017) that the very short form consisting of three items works just like a 17-item long form and a 9-item short form and was able to measure the construct of Work Engagement. In addition, it is accepted with this study that the form with 3 articles measures the Work Engagement structure in a valid way for different countries such as Finland, Japan, the Netherlands, Belgium (Flemish Region) and Spain. In the scale, it was found sufficient to use an item for each of the 3 sub-dimensions of the Work Engagement structure. These items and the dimensions they measure are as follows: "Vigor" dimension with item containing the expression, "At my work, I feel bursting with energy", "Dedication" dimension with the item containing the expression, "I am enthusiastic about my job", "Absorption" dimension with the item containing the expression, " "I am immersed in my work".

In our study, each item was assessed by the participants as (1) "Strongly Disagree", (2) "I Do Not Agree", (3) "I am Undecided", (4), I Agree, (5) "I Totally Agree", according to the five-point Likert Scale. In the internal consistency analysis of the data collected from 988 people working in the education sector, the Cronbach $\alpha$ value of the scale was found to be 0.89 , respectively. Cronbach $\alpha$ value of the scale in the internal consistency analysis of the research performed by Çankır and Şahin (2018) was found to be 0.83 .

2.2.2. Job Satisfaction Scale: In order to evaluate the level of job satisfaction of the employees, a 5-item Job Satisfaction Scale, consisting of 1 straight and 4 reverse items and developed by Babin and Boles (1988), was 
used. Turkish adaptation of the scale was done earlier by Büte (2011). Each item of the scale was evaluated by the participants as (1) "Strongly Disagree", (2) "I Do Not Agree", (3) "I am Undecided", (4), I Agree, (5) "I Totally Agree", according to the five-point Likert Scale. In the internal consistency analysis of the data collected from 988 people in our sample group, the Cronbach $\alpha$ value of the scale was found to be 0.80 , respectively.

2.2.3. The Intention to Quit Work Scale: In order to evaluate the attitudes of the participants towards their intention to quit, the 3-item intention to quit scale developed by Babin and Boles (1988) and adapted to Turkish by Büte (2011), was used. Each item of the scale, just as in the other scales, was evaluated by the participants as (1) "Strongly Disagree", (2) "I Do Not Agree", (3) "I am Undecided", (4), I Agree, (5) "I Totally Agree", according to the five-point Likert Scale. The Cronbach $\alpha$ value of the scale as a result of the internal consistency analysis of 988 participants was found to be 0.84 and it was observed that the scale was reliable.

2.2.4. Performance Scale: The participants' opinions about their performance were measured with a 4-item self-assessment scale. Previously, Kirkman and Rosen (1999) developed the scale, and the same scale was used in the study of Sigler and Pearson (2000). The scale was previously used by Çöl (2011), in the Turkish sample. Each item of the scale was assessed as (1) "Strongly Disagree", (2) "I Do Not Agree", (3) "I am Undecided", (4), I Agree, (5) "I Totally Agree", according to the five-point Likert Scale and Cronbach $\alpha$ value in the internal consistency analysis of 988 participants was found to be 0.87 , respectively.

\subsection{Procedure:}

The data of the research was collected online. The target audiences were informed in advance and the participants who accepted to participate in the research were sent a link to the web address of the survey questionnaire. The participants accessed and completed the questionnaire by clicking on this link. Data were collected over a period of approximately three months.

\subsection{Data Analysis:}

Analysis of the data collected from a total of 988 participants were performed by IBM SPSS Statistics 22 program. The frequency analysis was performed for the demographic data of the participants, the relationship between the variables was first evaluated by Pearson's r Correlation analysis. In order to test the model and hypotheses, Linear Simple Regression (Enter Method) and Linear Multiple Regression (Step Wise Method) analyses were performed. In order to test the mediating role of variables, the method suggested by Baron and Kenny (1986) and SOBEL tests were initially applied.

\section{Results:}

Pearson's r Correlation analysis was performed to determine the relations among the variables before conducting the hypothesis tests and testing the general research model. Correlation analysis results are presented in Table 2. As can be seen in the table, there is a moderately significant relationship between job satisfaction, which can be defined as positive working attitude, and work engagement, in congruence with previous studies $(\mathrm{r}: .50, \mathrm{p}<.01)$, and a negative relation was found between intention to quit and both of these two variables. In particular, the relation between job satisfaction and intention to quit (r: -73., $\mathrm{P}<.01)$ is at a high level. Even though, a significant relationship was found between job satisfaction and performance $(\mathrm{r}$ $\therefore 34, \mathrm{p}<.01)$, it is noteworthy that there is a higher level of relationship between the performance variable and the work engagement (r.74, $<<.01)$. These findings are consistent with Hypothesis 1 , in which we predicted a positive relationship between work engagement and job satisfaction; Hypothesis 2 , in which we predicted a negative relationship between work engagement and intention to quit; and Hypothesis 3 , in which we observed a negative correlation with job satisfaction and intention to quit. It also supports Hypothesis 4, Hypothesis 5 and Hypothesis 6 , which establish relationships between performance and other variables. These relations were also investigated by linear regression analyses. 
B. Çankır - S. Arıkan 11/2 (2019) 1133-1150

Table 2: Average of variables, standard deviations and correlations between variables

\begin{tabular}{|c|c|c|c|c|c|c|}
\hline & Avg. & Dev. & 1 & 2 & 3 & 4 \\
\hline Work Engagement & 6.18 & 2.63 & 1 & & & \\
\hline Job satisfaction & 10.52 & 4.02 & $.50^{* *}$ & 1 & & \\
\hline Intention to quit & 12.05 & 2.81 & $-.36^{* *}$ & $-.73^{* *}$ & 1 & \\
\hline Job Performance & 8.10 & 3.07 & $.74^{* *}$ & $.34^{* *}$ & $-.20^{* *}$ & 1 \\
\hline
\end{tabular}

${ }^{* *} \mathrm{p}<.01$

Simple and multiple linear regression analyses were conducted to examine the relationship between job satisfaction, work engagement and intention to quit. First of all, a simple regression analysis was conducted

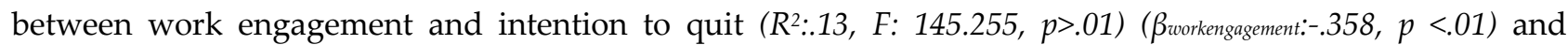
Hypothesis 2 was supported, and the predictability between job satisfaction and intention to quit was examined by a simple regression analysis. $\left(R^{2}: 53, F: 1101.078, p<.01\right)\left(\beta_{\text {jobsatisfaction: }}\right.$-.726) and Hypothesis 3 was also supported. Then, multiple linear regression analysis was used to investigate the predictability of job satisfaction and work engagement variables on intention to quit, as independent variables. According to the results of multiple linear regression analysis, when the work engagement and job satisfaction variables are included in the regression analysis at the same time, the predictability of work engagement on intention to

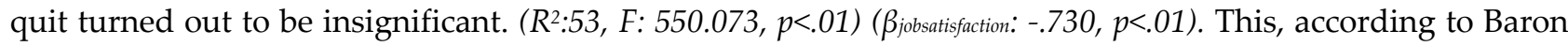
and Kenny's (1986) article, suggested that job satisfaction acted as a mediator in this relation. In this context, the predictability of work engagement on job satisfaction was tested by simple regression and the result was found to be significant. $\left(R^{2}: 25, F: 330.491, p<.01\right)(\beta: .501, p<.01)$ and Hypothesis 1 was also supported by the regression analysis. These analyses are consistent with the requirements of Baron and Kenny (1986) for mediation and indicated full mediation. The results of the regression analysis, which examines the relations among work engagement, job satisfaction and intention to quit, are presented in Table 3. In addition to these analyses, a SOBEL test was also performed to confirm the mediation role of job satisfaction in the relationship between the work engagement and the intention to quit, and it was confirmed that the variable of job satisfaction is the mediator variable (Sobel: -15.559 , Sd.H:.03, $p<.01$ ). The results are presented in Table 3 and visually in Figure 1.

Table 3: Prediction of Work Engagement and Job Satisfaction Variables on intention to quit:

\begin{tabular}{|c|c|c|c|}
\hline Dependent Variable & Intention to quit & & \\
\hline Independent Variable & Work Engagement & & \\
\hline Adjusted R²: .13 & F test: 145.255 & Significance: .000 & \\
\hline Variable in Equation & Beta & $\mathbf{T}$ & $\mathbf{P}$ \\
\hline Work Engagement & -.358 & -12.052 & .000 \\
\hline Dependent Variable & Intention to quit & & \\
\hline Independent Variable & Job satisfaction & & \\
\hline Adjusted R²: .53 & F test: 1101.078 & significance: .000 & \\
\hline Variable in Equation & Beta & $\mathbf{T}$ & $\mathbf{P}$ \\
\hline Job satisfaction & -.726 & -33.182 & .000 \\
\hline Dependent Variable & Job satisfaction & & \\
\hline Independent Variable & Work Engagement & & \\
\hline Adjusted R²: .25 & F test: 330.491 & Significance: .000 & \\
\hline Variable in Equation & Beta & $\mathbf{T}$ & $\mathbf{P}$ \\
\hline Work Engagement & .501 & 18.179 & .000 \\
\hline Dependent Variable & Intention to quit & & \\
\hline Independent Variables & $\begin{array}{l}\text { Work Engagement, } \\
\text { Satisfaction }\end{array}$ & & \\
\hline Adjusted R2: .53 & F test: 550.073 & Significance: .000 & \\
\hline Variable in Equation & Beta & $\mathbf{T}$ & $\mathbf{P}$ \\
\hline Job satisfaction & -.730 & $-28.8 f 2$ & .000 \\
\hline
\end{tabular}




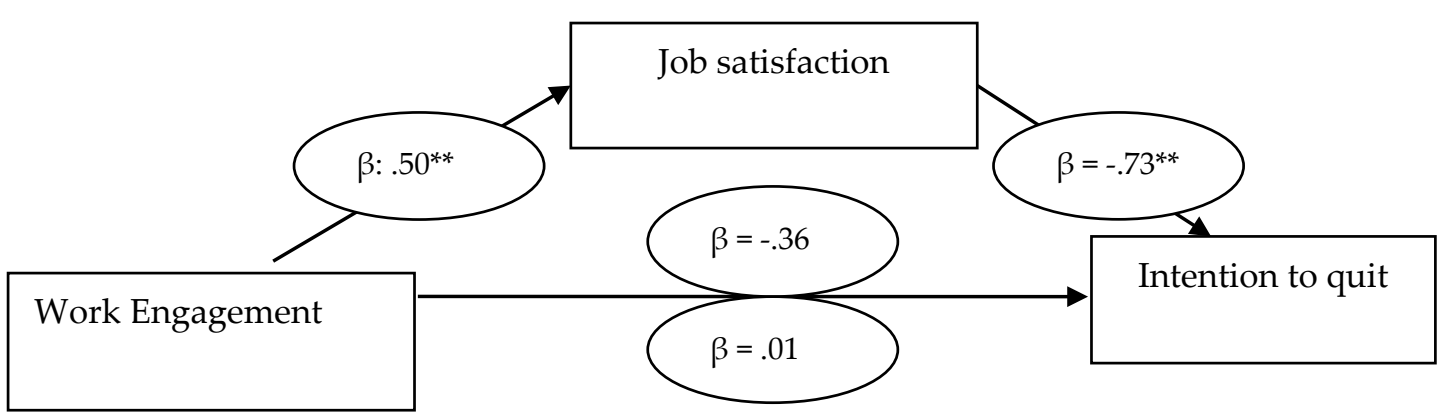

Figure 1: The Mediating Role of Job Satisfaction between Work Engagement and Intention to Quit

Simple and multiple linear regression analyses were conducted in order to examine the relationship between work engagement, job satisfaction and performance. First of all, the relation between work engagement and performance was examined by simple regression analysis and it was observed that work engagement predicted performance significantly. ( $\left.R^{2}: 54, F: 1170.062, p<.01\right)$ ( $\beta$ workengagement::737, $p<.01$ ) thus Hypothesis 4 was also supported. Later, the same analysis was also done to evaluate the relation between job satisfaction and performance. $\left(R^{2} 12, F: 132.233, p<.01\right)\left(\beta_{\text {jobsatisfaction: } . .344, p<.01)}\right.$ ) and Hypothesis 5 was also supported. It was observed that the predictability of job satisfaction variable disappeared when the variables of Work Engagement and Job Satisfaction were both included in regression analysis as independent variables. ( $R^{2}: 54$, F: 586.442, $p<.01$ ) ( $\beta$ workengagement:.754, $p<.01$ ). This situation has brought to mind that the work engagement acted as a mediator in the relation between job satisfaction and performance variables. It was also found by simple regression analysis that the job satisfaction also predicted the work engagement (R2 :25, $F: 330.491$, $p<.01)\left(\beta_{\text {jobsatisfaction:.501, }}<<.01\right.$ ). In addition, the SOBEL test has confirmed that the work engagement was the mediator variable in the relation between job satisfaction and performance (Sobel: 15.574, Sd.H:.02, p<.01).The results are presented in Table 4 and Figure 2.

Table 4: Prediction of Job Satisfaction and Work Engagement Variables on Performance:

\begin{tabular}{|c|c|c|c|}
\hline Dependent Variable & Performance & & \\
\hline Independent Variable & Work Engagement & & \\
\hline Adjusted R²: .54 & F test: 1170.062 & Significance: .000 & \\
\hline Variable in Equation & Beta & $\mathbf{T}$ & $\mathrm{p}$ \\
\hline Work Engagement & .737 & 34.206 & .000 \\
\hline Dependent Variable & Performance & & \\
\hline Independent Variable & Job satisfaction & & \\
\hline Adjusted $R^{2}: .12$ & F test: 132.233 & significance: .000 & \\
\hline Variable in Equation & Beta & $\mathbf{T}$ & $\mathrm{p}$ \\
\hline Job satisfaction & .344 & 11.499 & .000 \\
\hline Dependent Variable & Work Engagement & & \\
\hline Independent Variable & Job satisfaction & & \\
\hline Adjusted R²:.25 & F test: 330.491 & Significance: .000 & \\
\hline Variable in Equation & Beta & $\mathbf{t}$ & $\mathrm{p}$ \\
\hline Job Satisfaction & .501 & 18.179 & .000 \\
\hline Dependent Variable & Performance & & \\
\hline Independent Variables & $\begin{array}{l}\text { Work Engagement, } \\
\text { Satisfaction }\end{array}$ & & \\
\hline Adjusted R²:.54 & F test: 586.442 & Significance: .000 & \\
\hline Variable in Equation & Beta & $\mathbf{t}$ & $\mathrm{p}$ \\
\hline Work Engagement & .754 & 30.294 & .000 \\
\hline
\end{tabular}




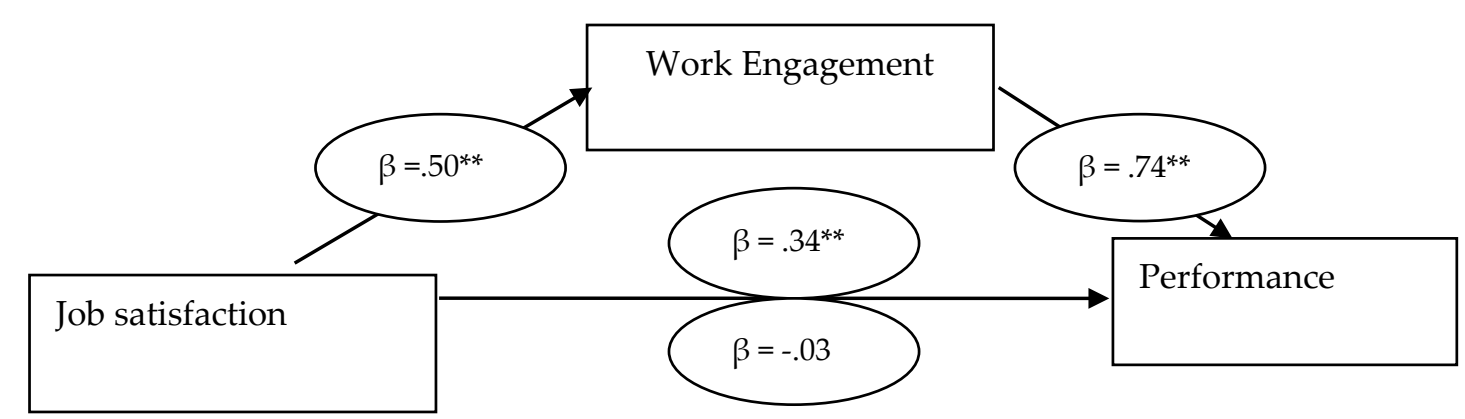

Figure 2: The Mediating Role of Work Engagement between Job Satisfaction and Performance

\section{Discussion}

Job satisfaction has been one of the most studied variables in occupational and organizational psychology. However, despite the positive relationship between job satisfaction and the performance, it is still controversial that in many studies the correlation coefficients are only low to moderate. This has led researchers to explore different employee attitudes that can better predict job performance as an alternative to job satisfaction. Work engagement as one of the variables for predicting positive work related results, is considered as one of the main topics and predictor variables of this research along with job satisfaction. Intention to quit and performance of employees' were examined as two outcome variables that might have an impact on the work results associated with employee attitudes. As it is a cross-sectional study, the relation between these variables were examined within the scope of our research and our research question has been formed as how the work engagement and job satisfaction might affect performance and the intention to quit, in relation with each other.

A correlation analysis was performed to roughly determine the relations between these four variables in the first stage and a significant and remarkable positive relationship was found between work engagement and job satisfaction. It was observed that both variables were negatively correlated with intention to quit, which can be defined as a negative employee attitude variable, and positively correlated with the performance variable, which is a positive work outcome variable. However, the association between work engagement and performance was found to be remarkably high compared to job satisfaction $(\mathrm{r}: .74, \mathrm{p}<.01)$. On the other hand job satisfaction had a higher and significantly negative relation with intention to quit when compared to work engagement variable $(\mathrm{r}: .-73, \mathrm{p}<.01)$.

Regression analyses were performed to test our hypotheses and to determine the mediators between antecedent and outcome variables. In all simple linear regression analysis, while job satisfaction and work engagement variables were alone, they predicted intention to quit and performance that we perceive as outcome variables, positively as expected. However, when we included both antecedent variables together in multiple regression analysis, the predictability of job satisfaction on performance and work engagement on intention to quit was eliminated. In this case, according to the suggestions of Baron and Kenny (1986), the mediator variable analysis was conducted and it was observed that the work engagement was the mediating variable between job satisfaction and performance. Job satisfaction was also found to be fully meditating the relationship between work engagement and the intention to quit that is, the variable of job satisfaction, predicting a much better and higher level of intention to quit, leads to a significant negative relationship between work engagement and intention to quit. These results were also confirmed by the SOBEL test.

These findings would be easier to explain when we focus on the definitions of work satisfaction and work engagement constructs. Job satisfaction is a situation, where the employee feels positive feelings about his / her work life and experiences (Demerouti and Cropanzono, 2010). On the other hand, work engagement covers the general approach to the work and working and includes the ability and willingness to do the work (Demerouti and Cropanzono, 2010; Schaufeli and Bakker, 2004). In this respect, the performance variable is a variable especially affected by the capacity and motivation of the employee to do the job; in order to hire higher performing employees, all enterprises are focused on identifying highly motivated candidates who have the necessary skills, talents and competencies, that is, the capacity and the willingness 
to do and work. (Schmitt and Chan, 1998; Ployhart, Schneider and Schmitt, 2005; Aamodt, 2012). On the other hand, as Brayfield and Crockett (1955), one of the first important review studies on job satisfaction, stated that job satisfaction is not sufficient to provide enough motivation to show high performance. In addition, studies showing low and medium-low associations between two variables support this idea (Wright, 2006; Lafaldano and Muchinsky, 1985; Petty, Mc Gee and Cavander, 1984, Vroom, 1964).

The research findings are also consistent with various motivational theories. One of the earlier but essential studies, Herzberg's Two Factor Theory, is one of these theories. In his Two Factor Theory, which is based on his work with accountants, Herzberg divided working conditions and work-related factors into two factors: hygiene factors and motivating factors. In this theory, Herzberg described the factors such as wages, working conditions, interpersonal relations, company policy and employee-manager relations as a hygiene factor and stated that the employee could experience job dissatisfaction and the desire to continue work would decrease. In this sense, the high negative relationship between job satisfaction and intention to quit is consistent with what Herzberg says about hygiene factor and dissatisfaction. For motivation that enables us to demonstrate better business performance, there is more than the satisfaction, and especially in terms of the nature of the job and the meaning that the employee places on them, such as the possibility of selfimprovement and progress, responsibility, the meaning of the job, regardless of the external conditions that will provide internal motivation (Robbins and Judge, 2012; DeShields, Kara and Kaynak, 2005). In this respect, the work engagement, which represents a positive attitude and motivation for the work and the work done, predicts the performance better than the job satisfaction. According to Wright (2006), Lyubomirsky, King and Diener (2005), Zelenski, Murphy and Jenkins, employee wellbeing seems to be a better variable than job satisfaction to predict performance. The work engagement is a variable that is more connected with employee well-being, with vigor and being energetic towards working, dedication and absorption to work which lead to flow experiences at work.

The variable of work engagement, which is characterized by a high level of energy and vigor towards the work, and a high level of dedication and concentration to the job, tends to be a variable associated with the employee rather than the external conditions such as the work environment, unlike job satisfaction. As a matter of fact, some previous studies showed that people who are engaged to work have certain personality traits. For example, according to Bakker, Tims and Derks (2012), employees who have a proactive personality tend to be more engaged to their work because they can increase the resources that motivate them by shaping their own business environment and can set new challenging goals. Akhtar, Boustani, Tsivrikos and Chamorro-Premuzic, (2015) also found that personality traits such as emotional intelligence, interpersonal sensitivity, perseverance, extraversion, compliance and self-discipline are related to work engagement. Bakker et al. (2012) also found a significant and positive relationship between the duty performance and the work engagement. Akhtar, Boustani, Tsivrikos, and Chamorro-Premuzic (2015) concluded in their study of the relationship between the Big -Five Personality Traits (Openness Conscientiousness - Extraversion - consociationalism - Neuroticism) and the work engagement that work engagement has positive relationships with the first four characteristics, and a negative relation with neuroticism. Accordingly, it can be concluded that the work engagement is related to personality variables and thus, predicts performance. It is possible that the dedication and absorption dimension of work engagement can also be related with the dedication to job goals. The Goal Setting Theory of Locke and Latham (1990) and Bandura's (1997) Social Cognitive Theory of motivation stresses the importance of dedication to goals and goal related feedback on increasing the performances of the employees.

Moreover absorption dimension of work engagement is related with the positive experience of Csikszentmihalyi's (1997) flow experience. Csikszentmihalyi (1997) defined flow as a state of consciousness in which a person is involved deeply what he/ she is doing that nothing else out of this activity seems to be so important and the person who is in a flow state enjoys the activity that he/she is doing. Flow is a positive experience that leads to positive emotions and according to Fredrickson's (2001) The Broaden-and-Build Theory of Positive Emotions, the positive emotions act as resources and have the capacity to broaden the view and performance of the people in a positive manner. This could be the case for highly engaged employees. They might be so engaged while they are working that they are absorbed to their tasks and experience the enjoyable statement of flow which is a rewarding experience by itself increasing their positive emotions, resources and work motivation for higher performance. Kuo and Ho's (2010) study showed that 
B. Çankır - S. Arıkan 11/2 (2019) 1133-1150

flow experiences of employees were directly and positively related with the service quality of the employees which is one of the most important indicators of job performance for employees. For further studies flow experience can also be added to the research model to understand its relations and role in the associations among our research variables.

One striking result of the study is that the average of job satisfaction of educators is low (10.52). In our country, it is possible that such a result has been reached as a result of the incompatibility between the expectations and desires of the educators and the sources of the work. Educators has the most important mission in raising the future generations of our country. In this respect, the causes of low job satisfaction should be questioned and solutions should be generated.

The most important limitation of the research is that it is cross-sectional. The fact that all data, including the performance variable, were taken from the employees and not taken from different evaluators, such as managers and customers, is also other limitation. Social desirability affect can be the other limitation of this study, since it consists a desire to give socially desired answers. The fact that all data were taken from the same people may have led to common method bias. In addition, it is a known fact that there are many different variables affecting the variables involved in the study. However, as all of these variables cannot be included in the research model within the scope of this research, the research is limited by ignoring the effects of these variables. All these limitations should be taken into consideration when interpreting the findings of this research.

\section{REFERENCES}

Aamodt, M. (2012). Industrial/organizational psychology: An applied approach. Nelson Education.

Akgün, M. C. (2017). "Çalışmaya tutkunluk ile işten ayrılma niyeti arasındaki ilişkide iş-aile çatışmasının biçimlendirici rolü, Istanbul Kultur University / Institute of Social Sciences (Unpublished PhD Thesis).

Akhtar, R., Boustani, L., Tsivrikos, D., \& Chamorro-Premuzic, T. (2015). The engageable personality: Personality and trait EI as predictors of work engagement. Personality and Individual Differences, 73, 4449.

Alfes, K., Shantz, A. D., Truss, C., \& Soane, E. C. (2013). The link between perceived human resource management practices, engagement and employee behaviour: a moderated mediation model. The international journal of human resource management, 24(2), 330-351.

Ardıç, K., \& Polatçı, S. (2009). Akhtar, R., Boustani, L., Tsivrikos, D., \& Chamorro-Premuzic, T. (2015). Erciyes University Faculty of Economics and Administrative Sciences Journal(32), 21-46.

Argyris, C. (1960). Understanding organizational behavior. Homewood, IL: The Dorsey Press.

Arslan, E. T., \& Demir, H. (2017). İşe Angaje Olma ve İş Tatmini Arasındaki İlişki: Hekim Ve Hemşireler Üzerine Nicel Bir Araştırma. Yönetim ve Ekonomi: Celal Bayar University Journal of the Faculty of Economics and Administrative Sciences, 24(2), 371-389.

Aşan, Ö.\& Erenler, E. (2008). İş tatmini ve yaşam tatmini ilişkisi. Journal of Süleyman Demirel University Faculty of Economics and Administrative Sciences13 (2), 203-216.

Babin, B. J., \& Boles, J. S. (1996). The effects of perceived co-worker involvement and supervisor support on service provider role stress, performance and job satisfaction. Journal of retailing, 72(1), 57-75.

Bakalcı, H. (2010). İşe Gönülden Adanma ve İnsan Kaynakları Yönetimi Uygulamaları Arasındaki ilişki ve Bir Örnek Olay(Unpublished Master's Thesis). Bahçeşehir University Institute of Social Sciences, Istanbul.

Bakker, A. B. (2011). An evidence-based model of work engagement. Current Directions in Psychological Science, 20(4), 265-269.

Bakker, A. B. (2017). Strategic and proactive approaches to work engagement. Organizational Dynamics, 46(2), 67-75.

Bakker, A. B., \& Albrecht, S. (2018). Work engagement: current trends. Career Development International, 23(1), 4-11.

Bakker, A. B., \& Bal, M. P. (2010). Weekly work engagement and performance: A study among starting teachers. Journal of Occupational and Organizational Psychology, 83(1), 189-206. 
B. Çankır - S. Arıkan 11/2 (2019) 1133-1150

Bakker, A. B., \& Demerouti, E. (2008). Towards a model of work engagement. Career development international, 13(3), 209-223.

Bakker, A. B., Demerouti, E., \& Verbeke, W. (2004). Using the job demands-resources model to predict burnout and performance. Human Resource Management: Published in Cooperation with the School of Business Administration, The University of Michigan and in alliance with the Society of Human Resources Management, 43(1), 83-104.

Bakker, A. B., Schaufeli, W. B., Leiter, M. P., \& Taris, T. W. (2008). Work engagement: An emerging concept in occupational health psychology. Work \& Stress, 22(3), 187-200.

Bakker, A. B., Tims, M., \& Derks, D. (2012). Proactive personality and job performance: The role of job crafting and work engagement. Human Relations, 65(10), 1359-1378.

Bandura, A. (1997). Self-efficacy: The exercise of control. Macmillan..

Begenirbaş, M., \& Çalışkan, A. (2014). Duygusal emeğin iş performansı ve işten ayrılma niyetine etkisinde kişilerarası çarpıklığın aracılık rolü. Business and Economics Research Journal, 5(2), 109-127.

Begley, T. M., \& Czajka, J. M. (1993). Panel analysis of the moderating effects of commitment on job satisfaction, intent to quit, and health following organizational change. Journal of Applied Psychology, $78(4), 552$.

Bhatnagar, J. (2012). Management of innovation: role of psychological empowerment, work engagement and intention to quit in the Indian context. The International Journal of Human Resource Management, 23(5), 928-951.

Borman, W. C., \& Motowidlo, S. M. (1993). Expanding the Criterion Domain to Include Elements of Contextual Performance. Personnel Selection in Organizations. San Francisco: Jossey-Bass.

Brayfield, A. H., \& Crockett, W. H. (1955). Employee attitudes and employee performance. Psychological bulletin, 52(5), 396.

Büte, M. (2011). Kayırmacılık algısı ile iş tatmini, olumsuz söz söyleme ve işten ayrılma niyeti arasındaki ilişki. Electronic Journal of Social Sciences, 10(36), 187-203.

Campbell, J. P., McHenry, J. J., \& Wise, L. L. (1990). Modeling job performance in a population of jobs. Personnel psychology, 43(2), 313-575.

Csikszentmihalyi, M. (1997). Finding Flow: The Psychology of Engagement with Everyday Life. HarperCollins, New York.

Çankır, B. (2010). Yalın Düşünce Sistemini Uygulayan Kurumlarla Uygulamayan Kurumlarda Çalışanlarda Örgütsel Vatandaşlık Davranışı, (Unpublished Master's Thesis), İstanbul: Marmara University Institute of Social Sciences,

Çankır, B. (2016). Çalışmaya Tutkunluk ve Tükenmişliğin Örgütsel Vatandaşlık Davranışı Üzerinde Etkisi ve Bir Uygulama (Unpublished PhD Thesis). Istanbul University Social Sciences Institute, İstanbul

Çankır, B., \& Şahin, S. (2018). Medya-Kültür ve Sanat Alanında Çalışanların Psikolojik İyi-Oluşları İle İşten Ayrılma Niyetleri Arasındaki İlişkide Çalışmaya Tutkunluğun Aracı Rolü. International Journal of Economic and Administrative Studies333-346.

Çankır, B., \& Yener, B. (2017). Işs'te Pozitif Davranış. Konya: Çizgi Kitapevi.

Çekmecelioğlu, H. (2006). İş tatmini ve örgütsel bağlllık tutumlarının işten ayrılma niyeti ve verimlilik üzerindeki etkilerinin değerlendirilmesi: Bir araştırma. ISGUC The Journal of Industrial Relations and Human Resources, 8(2), 153-168.

Çekmecelioğlu, H. G. (2005). Örgüt İkliminin İş Tatmini ve İşten Ayrılma Niyeti Üzerindeki Etkisi: Bir Araştırma. C.U. Journal of Economics and Administrative Sciences6 (2), 23-39.

Çelik, M., \& Çıra, A. (2013). Örgütsel vatandaşlık davranışının iş performansı ve işten ayrılma niyeti üzerine etkisinde aşırı iş yükünün aracılık rolü. Ege Akademik Bakış, 13(1), 11-20.

Ceylan, A., \& Ulutürk, Y. H. (2006). Rol belirsizliği, rol çatışması, iş tatmini ve performans arasındaki ilişkiler. Doğuş University Journal, 7 (1) 2006, 48-58.

Christian, M. S., Garza, A. S., \& Slaughter, J. E. (2011). Work engagement: A quantitative review and test of its relations with task and contextual performance. Personnel psychology, 64(1), 89-136. 
B. Çankır - S. Arıkan 11/2 (2019) 1133-1150

Çöl, Güner (2011). Algılanan güçlendirmenin işgören performansı üzerine etkileri. Doğuş Üniversitesi Dergisi, 9(1), 35-46.

Cote, S., \& Morgan, L. M. (2002). A longitudinal analysis of the association between emotion regulation, job satisfaction, and intentions to quit. Journal of Organizational Behavior, 23(8), 947-962.

Damavandi, M. E., \& Kashani, Z. S. (2010). Effect of mastery learning method on performance, attitude of the weak students in chemistry. Procedia-Social and Behavioral Sciences, 5, 1574-1579.

Demerouti, E., \& Cropanzano, R. (2010). “From thought to action: Employee work engagement and job performance". Eds. Arnold Bakker, Michael P.Leiter, Work engagement: A handbook of essential theory and research, 65, 147-163.

Demerouti, E., Bakker, A. B., \& Gevers, J. M. (2015). Job crafting and extra-role behavior: The role of work engagement and flourishing. Journal of Vocational Behavior, 91, 87-96.

Demir Harputluoğlu, D. \& Dönmez Polat, D. (2017). İşe Tutkunluk ve İş-Aile-İş Çatışmasının İşten Ayrılma Niyetibe Etkisi: Konaklama İşletmelerinde Bir Uygulama. SOBIDDER, 4(13), 435-450.

DeShields Jr, O. W., Kara, A., \& Kaynak, E. (2005). Determinants of business student satisfaction and retention in higher education: applying Herzberg's two-factor theory. International journal of educational management, 19(2), 128-139.

Erdil, O., Keskin, H., İmamoğlu, S. Z., \& Erat, S. (2011). Yönetim tarzı ve çalışma koşulları, arkadaşlık ortamı ve takdir edilme duygusu ile iş tatmini arasındaki ilişkiler: Tekstil sektöründe bir uygulama. Doğuş University Journal, 5 (1), 17-26.

Erkuş, A., \& Fındıklı, M. A. (2013). Psikolojik sermayenin iş tatmini, iş performansı ve işten ayrılma niyeti üzerindeki etkisine yönelik bir araştırma. Istanbul University Journal of the School of Business Administration, 42(2), 302-318.

Fabi, B., Lacoursière, R., \& Raymond, L. (2015). Impact of high-performance work systems on job satisfaction, organizational commitment, and intention to quit in Canadian organizations. International Journal of Manpower, 36(5), 772-790.

Fredrickson, B. L. (2001). The role of positive emotions in positive psychology: The broaden-and-build theory of positive emotions. American psychologist, 56(3), 218-226.

Fredrickson, B. L. (2003). Positive emotions and upward spirals in organizations. Positive organizational scholarship, 163-175.

Garczynski, A. M., Waldrop, J. S., Rupprecht, E. A., \& Grawitch, M. J. (2013). Differentiation between work and nonwork self-aspects as a predictor of presenteeism and engagement: Cross-cultural differences. Journal of Occupational Health Psychology, 18(4), 417.

Giallonardo, L. M., Wong, C. A., \& Iwasiw, C. L. (2010). Authentic leadership of preceptors: predictor of new graduate nurses' work engagement and job satisfaction. Journal of nursing management, 18(8), 993-1003.

Gierveld, J. H., \& Bakker, A. B. (2005). De invloed van de secretaresse [The influence of the secretary]. Diemen, The Netherlands: Manpower.

Gouldner, A. W. (1960). The norm of reciprocity: A preliminary statement. American sociological review, 161178.

Gürbüz, S., \& Yüksel, M. (2011). Çalışma ortamında duygusal zekâ: İş performansı, iş tatmini, örgütsel vatandaşlık davranışı ve bazı demografik özelliklerle ilişkisi. Doğuş University Journal9 (2), 174-190.

Hakanen, J. J., Bakker, A. B., \& Schaufeli, W. B. (2006). Burnout and work engagement among teachers. Journal of school psychology, 43(6), 495-513.

Halbesleben, J. R., \& Wheeler, A. R. (2008). The relative roles of engagement and embeddedness in predicting job performance and intention to leave. Work \& Stress, 22(3), 242-256.

Hallberg, U. E., \& Schaufeli, W. B. (2006). "Same same" but different? Can work engagement be discriminated from job involvement and organizational commitment?. European psychologist, 11(2), 119-127. 
B. Çankır - S. Arıkan 11/2 (2019) 1133-1150

Høigaard, R., Giske, R., \& Sundsli, K. (2012). Newly qualified teachers' work engagement and teacher efficacy influences on job satisfaction, burnout, and the intention to quit. European Journal of Teacher Education, 35(3), 347-357.

Judge, T. A., Thoresen, C. J., Bono, J. E., \& Patton, G. K. (2001). The job satisfaction-job performance relationship: A qualitative and quantitative review. Psychological bulletin, 127(3), 376.

Kahn, W. A. (1990). Psychological conditions of personal engagement and disengagement at work. Academy of management journal, 33(4), 692-724.

Kahn, W. A. (2012). "The essence of engagement: Lessons from the field". Ed. by. Simon L. Albrecht, Handbook of Employee Engagement: Perspectives, Issues, Research and Practice, Cheltenham, Edward Elgar Publishing, pp. 20-30.

Kahn, W. A., \& Fellows, S. (2013). Employee engagement and meaningful work. In B. J. Dik, Z. S. Byrne, \& M. F. Steger (Eds.), Purpose and meaning in the workplace (pp. 105-126). Washington, DC, US: American Psychological Association.

Kanten, P., \& Yeşiltaş, M. (2013). Pozitif Örgütsel Davranışlar Üzerine Kavramsal Bir İnceleme. Süleyman Demirel University Vizyoner Journal, 4(8), 83-106.

Kirkman, B. L., \& Rosen, B. (1999). Beyond self-management: Antecedents and consequences of team empowerment. Academy of Management journal, 42(1), 58-74.

Kompaso, S. M., \& Sridevi, M. S. (2010). Employee engagement: The key to improving performance. International journal of business and management, 5(12), 89.

Kömürcüoğlu, H. (2003). Belirsizlik ortamında iş tatmini ve işe bağlllık. ISGUC The Journal of Industrial Relations and Human Resources, 5(1).

Koyuncu, M., Burke, R. J., \& Fiksenbaum, L. (2006). Work engagement among women managers and professionals in a Turkish bank: Potential antecedents and consequences. Equal Opportunities International, 25(4), 299-310.

Kuo, T. H., \& Ho, L. A. (2010). Individual difference and job performance: The relationships among personal factors, job characteristics, flow experience, and service quality. Social Behavior and Personality: an international journal, 38(4), 531-552.

Lafaldano, M.T. ve Muchinsky P.M. (1985). Job Satisfaction and Job Performance: A Meta Analysis. Psychological Bulletin, 97, 251-273.

Leiter, M. P. \& Maslach, C. (2004). "Areas of Worklife: A Structured Approach to Organizational Predictors of Job Burnout, Emotional and Physiological Processes and Positive Intervention Strategies", Ed. by. Daniel C. Ganster, Pamela L. Perrewe, Research in Occupational Stress and Well Being, Vol.3, pp. 91-134.

Lim, A. J. P., Loo, J. T. K., \& Lee, P. H. (2017). The impact of leadership on intention to quit: The mediating role of organizational commitment and job satisfaction. Journal of Applied Structural Equation Modeling, $1(1), 27-41$.

Locke, E. A. (1969). What is Job Satisfaction? Organizational Behavior and Human Light at the End of the Tunnel. Psychological Science, 1(4), 240-246.

Locke, E. A., \& Latham, G. P. (1990). A theory of goal setting \& task performance. Prentice-Hall, Inc.

Lum, L., Kervin, J., Clark, K., Reid, F., \& Sirola, W. (1998). Explaining nursing turnover intent: job satisfaction, pay satisfaction, or organizational commitment?. Journal of Organizational Behavior: The International Journal of Industrial, Occupational and Organizational Psychology and Behavior, 19(3), 305-320.

Luthans, F., \& Peterson, S. J. (2002). Employee engagement and manager self-efficacy. Journal of management development, 21(5), 376-387.

Lyubomirsky, S., King, L., \& Diener, E. (2005). The benefits of frequent positive affect: Does happiness lead to success?. Psychological bulletin, 131(6), 803.

Maslach, C., \& Leiter, M. P. (1997). The truth about burnout: How organizations cause stress and what to do about it. San Francisco, Jossey-Bass.

McIntosh C., Turnbull, J. (2005). Oxford Advanced Learner's Dictionary: International Student's Edition, Ed. by., Sally Wehmeier, Oxford: Oxford University Press. 
B. Çankır - S. Arıkan 11/2 (2019) 1133-1150

Milani, K. (1975). The relationship of participation in budget-setting to industrial supervisor performance and attitudes: a field study. The accounting review, 50(2), 274-284.

Noh, M., \& Johnson, K. K. (2016). Effect of Workplace Characteristics on Part-Time Apparel Sales Associates' intention to quits. International Journal of Costume and Fashion, 16(1), 37-53.

Oates, W. E. (1971). Confessions of a workaholic: The facts about work addiction. World Publishing Company.

Öngöre, Ö. (2013). İşle Bütünleşme Ölçeği Türkçe Formunun Güvenilirlik ve Geçerlilik Çalışması. Journal of Kastamonu University Faculty of Economics and Administrative Sciences, 2nd(2), 50-50.

Özsoy, E., Filiz, B., \& Semiz, T. (2013). İşkoliklik ve çalışmaya tutkunluk arasındaki ilişkiyi belirlemeye yönelik sağlık sektöründe bir araştırma. Journal of Social Sciences and Humanities, 5(2), 59-68.

Park, Y. K., Song, J. H., Yoon, S. W., \& Kim, J. (2014). Learning organization and innovative behavior: The mediating effect of work engagement. European Journal of Training and Development, 38(1/2), 75-94.

Petty, M. M., McGee, G. W., \& Cavender, J. W. (1984). A meta-analysis of the relationships between individual job satisfaction and individual performance. Academy of management Review, 9(4), 712-721.

Ployhart, R. E., Schneider, B., \& Schmitt, N. (2005). Staffing organizations: Contemporary practice and theory. CRC Press.

Poon, J. M. (2004). Effects of performance appraisal politics on job satisfaction and intention to quit. Personnel review, 33(3), 322-334.

Poyraz, K., \& Kama, U. B. (2008). Algılanan iş güvencesinin, iş tatmini, örgütsel bağlllık ve işten ayrılma niyeti üzerindeki etkilerinin incelenmesi. Journal of Süleyman Demirel University Faculty of Economics and Administrative Sciences13 (2), 203-216.

Rayton, B. A., \& Yalabik, Z. Y. (2014). Work engagement, psychological contract breach and job satisfaction. The International Journal of Human Resource Management, 25(17), 2382-2400.

Reijseger, G., Peeters, M. C., Taris, T. W., \& Schaufeli, W. B. (2017). From motivation to activation: why engaged workers are better performers. Journal of Business and Psychology, 32(2), 117-130.

Rich, B. L., Lepine, J. A., \& Crawford, E. R. (2010). Job engagement: Antecedents and effects on job performance. Academy of management journal, 53(3), 617-635.

Ritchie, H., \& Newby, T. J. (1989). Instruction: Classroom lecture/discussion vs. live televised instruction: A comparison of effects on student performance, attitude, and interaction. American Journal of Distance Education, 3(3), 36-45.

Robbins, S. P., \& Judge, T. (2012). Essentials of organizational behavior.Pearson.

Rousseau, D. (1995). Psychological contracts in organizations: Understanding written and unwritten agreements. Sage Publications.

Rousseau, D. M. (1989). Psychological and implied contracts in organizations. Employee responsibilities and rights journal, 2(2), 121-139.

Şahin, S., \& Çankır, B. (2018). İş Tatmininin İş Performansına Etkisinde Çalışmaya Tutkunluğun Aracı Rolü: Satış ve Pazarlama Sektöründe Bir Araştırma. International Journal of Economic and Administrative Studies389-402

Saks, A. M. (2006). Antecedents and consequences of employee engagement. Journal of managerial psychology, 21(7), 600-619.

Saks, A. M., \& Gruman, J. A. (2018). Socialization resources theory and newcomers' work engagement: a new pathway to newcomer socialization. Career Development International, 23(1), 12-32.

Salanova, M., Agut, S., \& Peiró, J. M. (2005). Linking organizational resources and work engagement to employee performance and customer loyalty: the mediation of service climate. Journal of applied Psychology, 90(6), 1217.

Schaufeli, W. B., \& Bakker, A. B. (2003). Utrecht work engagement scale: Preliminary manual. Occupational Health Psychology Unit, Utrecht University, Utrecht, 26.

Schaufeli, W. B., \& Bakker, A. B. (2004). Job demands, job resources, and their relationship with burnout and engagement: A multi-sample study. Journal of Organizational Behavior: The International Journal of Industrial, Occupational and Organizational Psychology and Behavior, 25(3), 293-315. 
B. Çankır - S. Arıkan 11/2 (2019) 1133-1150

Schaufeli, W. B., \& Bakker, A. B. (2010). “Defining and measuring work engagement: Bringing clarity to the concept."Eds. By. Micheal P. Leiter, Arnold Bakker, Work engagement: A handbook of essential theory and research, pp. 10-24.

Schaufeli, W. B., M. Salanova, V. Gonzalez-Roma, ve Bakker,A. B. (2002). The Measurement of Engagement and Burnout: A Two Sample of Confirmatory Factor Analytic Approach. Journal of Happiness Studies, 3, 71-92.

Schaufeli, W. B., Shimazu, A., Hakanen, J., Salanova, M., \& De Witte, H. (2017). An Ultra-Short Measure for Work Engagement: The UWES-3 validation across five countries.

Schaufeli, W. B., Taris, T. W., \& Bakker, A. B. (2006). “Dr. Jekyll or Mr. Hyde: On the differences between work engagement and workaholism, Research companion to working time and work addiction", Ed. by. Ronald J. Burke, Research Companion to Working Time and Work Addiction, Cheltenham, Edward Elgar, 2006, p. 193-217.

Schmitt, N., \& Chan, D. (1998). Personnel selection: A theoretical approach. Sage.

Schneider, B., ve Snyder, R. A. (1975). Some Relationships Between Job Satisfaction and Organization Climate. Journal of Applied Psychology, 60(3), 318.

Scott, D., Bishop, J. W., \& Chen, X. (2003). An examination of the relation of employee involvement with job satisfaction, employee cooperation, and intention to quit in US invested enterprise in China. The International Journal of Organizational Analysis, 11(1), 3-19.

Seçer, B. (2009). “İçsel İşten Ayrılma: Nedenleri, Ölçülmesi ve Önlenmesi”. Ed. Aşkın Keser, Çalışma Yaşamında Davranış: Güncel Yaklaşımlar, Kocaeli: Umuttepe Yayınevi, s: 549-566.

Seppälä, P., Hakanen, J., Mauno, S., Perhoniemi, R., Tolvanen, A., \& Schaufeli, W. (2015). Stability and change model of job resources and work engagement: A seven-year three-wave follow-up study. European Journal of Work and Organizational Psychology, 24(3), 360-375.

Shimazu, A., \& Schaufeli, W. B. (2009). Is workaholism good or bad for employee well-being? The distinctiveness of workaholism and work engagement among Japanese employees. Industrial health, 47(5), 495-502.

Shuck, B., \& Wollard, K. (2010). Employee engagement and HRD: A seminal review of the foundations. Human Resource Development Review, 9(1), 89-110.

Taş, A. (2018). İş Yükü ile İş-Aile Çatışması Arasındaki İlişkide İşe Tutkunluk ve Algılanan Örgütsel Desteğin Etkisi: Alışveriş Merkezi Çalışanları Üzerinde Bir Araştırma.; Hacettepe Üniversity Institute of Social Sciences (Unpublished Ph.D. Thesis) Ankara.

TDK,

Güncel

Sözlük.

http://www.tdk.gov.tr/index.php?option=com_gts\&arama=gts\&guid=TDK.GTS.5b9237204286c9.15242

181. Date of access: 10.09 .2018

Tett, R. P., \& Meyer, J. P. (1993). Job satisfaction, organizational commitment, intention to quit, and turnover: path analyses based on meta-analytic findings. Personnel psychology, 46(2), 259-293.

Turgut, T. (2010). “Çalışmaya Tutkunluk”, Ed. by. Güler İslamoğlu, Kurumlarda İyilik de Var, Ankara, Nobel Yayıncilik.

Turgut, T. (2013). Başarı hedef yönelimleri ve iş özelliklerinin çalışmaya tutkunluk üzerindeki katkıları. Istanbul University Journal of the School of Business, 42(1), 1-25.

Tuten, T. L., \& Neidermeyer, P. E. (2004). Performance, satisfaction and turnover in call centers: The effects of stress and optimism. Journal of Business Research, 57(1), 26-34.

van Berkel, J., Boot, C. R., Proper, K. I., Bongers, P. M., \& van der Beek, A. J. (2014). Effectiveness of a worksite mindfulness-related multi-component health promotion intervention on work engagement and mental health: results of a randomized controlled trial. PloS one, 9(1), e84118.

Vroom, V. (1964). Work and motivation. John Willey \& Sons, New York

Warr, P., \& Inceoglu, I. (2012). Job engagement, job satisfaction, and contrasting associations with person-job fit. Journal of occupational health psychology, 17(2), 129. 
Wefald, A. J., \& Downey, R. G. (2009). Job engagement in organizations: fad, fashion, or folderol?. Journal of Organizational Behavior: The International Journal of Industrial, Occupational and Organizational Psychology and Behavior, 30(1), 141-145.

Welch, M. (2011). The evolution of the employee engagement concept: communication implications. Corporate Communications: An International Journal, 16(4), 328-346.

Wright, T. A. (2006). The emergence of job satisfaction in organizational behavior: A historical overview of the dawn of job attitude research. Journal of Management History, 12(3), 262-277.

Xanthopoulou, D., Bakker, A. B., Demerouti, E., \& Schaufeli, W. B. (2009). Reciprocal relationships between job resources, personal resources, and work engagement. Journal of Vocational behavior, 74(3), 235-244.

Yalabik, Z. Y., Popaitoon, P., Chowne, J. A., \& Rayton, B. A. (2013). Work engagement as a mediator between employee attitudes and outcomes. The International Journal of Human Resource Management, 24(14), 2799-2823.

Yazıcıŏlu, İ. (2009). Konaklama işletmelerinde işgörenlerin örgütsel güven duygulari ile iş tatmini ve işten ayrilma niyetleri üzerine bir alan araştirmasi. Elektronik Sosyal Bilimler Dergisi, 8(30), 235-249.

Yazıcıŏlu, İ. (2010). Örgütlerde iş tatmini ve işgören performansı ilişkisi: Türkiye ve Kazakistan karşılaştırması. bilig, 55(1), 243-264.

Yeh, C. M. (2013). Tourism involvement, work engagement and job satisfaction among frontline hotel employees. Annals of Tourism Research, 42, 214-239.

Zelenski, J. M., Murphy, S. A., \& Jenkins, D. A. (2008). The happy-productive worker thesis revisited. Journal of Happiness Studies, 9(4), 521-537.

Zimmerman, R. D., \& Darnold, T. C. (2009). The impact of job performance on employee intention to quits and the voluntary turnover process: A meta-analysis and path model. Personnel Review, 38(2), 142-158. 